\title{
Genetic variation and genotype by environment interaction in the susceptibility of Abies nordmanniana (Steven) Spach to the fungus Neonectria neomacrospora (Booth \& Samuels) Mantiri \& Samuels
}

\author{
Jing Xu ${ }^{1}$ (D) - Ole K. Hansen ${ }^{1} \cdot$ Iben M. Thomsen ${ }^{1} \cdot$ Ulrik B. Nielsen ${ }^{1}$
}

Received: 30 June 2017 / Accepted: 9 January 2018 / Published online: 8 February 2018

(C) INRA and Springer-Verlag France SAS, part of Springer Nature 2018

\begin{abstract}
- Key message Pronounced clonal variation and moderate to high broad-sense heritability estimates of susceptibility to Neonectria neomacrospora were found in Abies nordmanniana in three sites. Significant genotype by environment $(\mathbf{G} \times \mathbf{E})$ interaction was detected across sites.

- Context Nordmann fir, a widely used Christmas tree species in Europe, has, since 2011, been increasingly damaged by a canker disease caused by Neonectria neomacrospora.

- Aims The objective was to study the genetic variation and genotype by environment interaction in the susceptibility of Nordmann fir to N. neomacrospora.

- Methods Damage caused by N. neomacrospora was evaluated using a visual scale in three Nordmann fir clonal seed orchards in Denmark, partly containing the same clones.

- Results Damage due to N. neomacrospora was substantial at all three sites, and no clone was completely resistant to $N$. neomacrospora, but a large genetic variation in the susceptibility was detected among clones. Estimates of single-site individual broad-sense heritability for susceptibility varied between 0.38 and 0.47 . The average type-B genetic correlation for damage score across sites was 0.34 .

- Conclusion Genetic variation was very pronounced, and significant $\mathrm{G} \times \mathrm{E}$ interactions were detected for susceptibility. Further investigations of narrow-sense heritability, expression of the trait in younger material, and identification of the cause of $\mathrm{G} \times \mathrm{E}$ for $N$. neomacrospora susceptibility in Nordmann fir across different sites are recommended.
\end{abstract}

Keywords Broad-sense heritability $\cdot$ Resistance breeding $\cdot$ Spatial genetic analysis

\section{Handling Editor: Cécile Robin}

Contribution of the co-authors

Jing $\mathrm{Xu}$ contributed in analyzing the data and writing the manuscript.

Ole K. Hansen contributed in supervising, reviewing, and writing the manuscript.

Iben M. Thomsen contributed in supervising and paper reviewing.

Ulrik B. Nielsen contributed in designing the study, supervising the work, and reviewing and writing the manuscript.

Jing $\mathrm{Xu}$

jx@ign.ku.dk

Ole K. Hansen

okh@ign.ku.dk

Iben M. Thomsen

imt@ign.ku.dk
Ulrik B. Nielsen

ubn@ign.ku.dk

1 Department of Geosciences and Natural Resource Management, University of Copenhagen, Rolighedsvej 23, 1958 Frederiksberg $\mathrm{C}$, Denmark 


\section{Introduction}

Nordmann fir (Abies nordmanniana (Steven) Spach) originates from the eastern coast of the Black Sea, including the Caucasus of Russia, Georgia, and the northeastern parts of Turkey (Liu 1971), and the species is of considerable ecological and economic importance. Around 45 million Nordmann firs are used as Christmas trees in Europe every year, and Denmark is a major producer with around 11 million trees produced per year (Claus Jerram Christensen Personal Communication 2016). A Danish breeding program for Nordmann fir has been ongoing since 1992 (Nielsen 1994) and, under the auspices of the Danish Nature Agency, a number of mainly grafted seed orchards have been established. A total of nearly 400 selected trees have been grafted so far. The breeding program aims to create high-quality Christmas trees that meet the needs of consumers in various markets (Nielsen and Chastagner 2005).

However, since 2011, a canker disease caused by Neonectria neomacrospora (Booth \& Samuels) Mantiri \& Samuels (anamorph Cylindrocarpon cylindroides Wollenw.) (Mantiri et al. 2001) has been detected in the true firs (genus Abies) grown as exotics in Norway and Denmark, including in Nordmann fir Christmas tree stands (Talgø et al. 2013). According to a survey carried out by the Danish Christmas Tree Association in 2013, the incidence of Neonectria canker in Danish Christmas tree stands increased substantially from 2011 to 2013. In 2013, 26\% of the Danish Christmas tree stands were estimated to have symptoms of $N$. neomacrospora infestation (Proschowsky 2014). The disease can be diagnosed by symptoms like dieback from the tip of infected branches; canker wounds with dead tissue below the bark, heavy resin flow, and white conidial sporodochia (Cylindrocarpon); and red fruiting bodies of $N$. neomacrospora on the bark of infected trees (Talgø et al. 2012). The first observation of $N$. neomacrospora (reported as Cylindrocarpon) was in 1910 on grafted Abies concolor in northern Germany (Wollenweber 1913), and later on, both Lang (1981) and John (2011) reported outbreaks of the disease in Germany. In Norway, canker disease caused by $N$. neomacrospora was observed on several Abies species (Robak 1951; Talgø et al. 2012). Neonectria neomacrospora has also been considered as a biocontrol agent for hemlock dwarf mistletoe (Rietman 2004; Rietman et al. 2005), but to date, the origin of the fungus remains unclear. The infection of $N$. neomacrospora has been shown to have a spatial pattern in Christmas tree stands, which has led to the hypothesis that $N$. neomacrospora resembles the closely related fungus Neonectria ditissima, which disperses ascospores via rain and wind splashes and macroconidia via rain splashes (Gómez-Cortecero et al. 2016). However, further studies need to be carried out to confirm that.

Management of this canker disease is essential to ensure profitable Christmas tree production. Compared to conventional uses of forest trees, e.g., for timber production, Christmas trees as a crop have a low tolerability threshold for attacks by pests, since just minor damage can devalue the trees or make them unsalable. Hence, it is desirable to identify stable sources of resistance and exploit them to develop resistant genotypes of Nordmann fir through breeding. A natural infestation by $N$. neomacrospora in three Nordmann fir clonal seed orchards (CSOs) containing shared genetic material gave us the opportunity to study the genetic variation in susceptibility to $N$. neomacrospora at the individual tree level. This study provides important knowledge about genetic variation that can be used to develop breeding based on testing of clones or progeny for selecting more resistant parents for the next breeding cycle.

The first step in resistance breeding must be to carry out a simple field assessment to identify the extent and distribution of disease infection across the forest area of concern, which can assist in understanding the importance of the disease and its effect on economic and ecological values (Carson and Carson 1989). Visual scores can be cost-effectively used to describe variation in susceptibility/resistance (Carson and Carson 1989; Joshi et al. 2007; Kirisits and Freinschlag 2012; Lobo et al. 2014; McKinney et al. 2011). When using natural infection to evaluate genetic differences, there is a risk of higher environmental influence, due to more variable site conditions, than seen in traditional planned field trial evaluations (Fu et al. 1999; Resende et al. 2006), e.g., because of variable infection pressure. In order to minimize the potentially high spatial heterogeneity and to increase the accuracy of the estimates of genetic effects, spatial analysis using the twodimensional separable autoregressive error model, with parameters estimated using restricted maximum likelihood (REML) (Cullis and Gleeson 1991), has been increasingly applied in forest field trials (Costa e Silva et al. 2001; Dutkowski et al. 2002; Dutkowski et al. 2006; Ye and Jayawickrama 2008). Studies of genotype by environment $(\mathrm{G} \times \mathrm{E})$ interactions provide knowledge of genotype performance stability across different sites (Burdon 1977), which helps in making decisions for breeding and deployment programs to select superior clones for specific sites or across different sites (Ogut et al. 2014).

Since $N$. neomacrospora is a newly emerged disease in the Abies genus, only two studies of $N$. neomacrospora resistance in Abies species exist. One is by Skulason et al. (2017), who studied $N$. neomacrospora susceptibility in provenances of A. lasiocarpa. The other is by Nielsen et al. (2017), who studied species variation of the genus Abies in susceptibility to $N$. neomacrospora. No study has evaluated the withinspecies susceptibility of Nordmann fir to $N$. neomacrospora nor the susceptibility at the individual tree level in any other Abies species. Genetic variation at the individual tree level is the "fuel" of tree breeding, and identifying Nordmann fir trees with natural genetic resistance to this fungus may therefore be 
of great importance for Christmas tree production. From a breeding point of view, it is also interesting to know if clonal responses to a disease are stable across sites. Thus, estimating the genotype by environment interaction $(\mathrm{G} \times \mathrm{E})$ is also desirable in developing breeding programs so that appropriate decisions can be made about testing, deployment, and selection (Codesido and Fernández-López 2009).

The current study is based on a field visual score assessment of natural $N$. neomacrospora infection in three Nordmann fir CSOs in Denmark. Two objectives were addressed: (1) to evaluate potential genetic variation in susceptibility to $N$. neomacrospora among clones of Nordmann fir and estimate genetic parameters, such as genotypic variation and broad-sense heritability within sites, and (2) to explore genotype by environment interaction for $N$. neomacrospora susceptibility between sites.

\section{Material and methods}

\subsection{Materials}

For the field evaluation study, a total of 4759 grafted trees from 125 Nordmann fir clones in three Danish approved CSOs (approval nos. FP.251, FP.259, and FP.272) (Danish Agrifish Agency 2016) were included (Table 1; Fig. 1). Clones were grafted from two selected materials, Tversted material and F.20 material. The Tversted material was selected in 1992 from two Danish approved stands planted around 1900, Tversted Dune Forest Departments 623 (F.527) and 599 (F.526), of presumed Borjomi origin in the central Caucasus (Løfting 1973). The F.20 material originates from the Danish approved stand F.20 Boller, also of presumed Borjomi origin, but clones were selected (in

Table 1 Site characteristics of the three evaluated Nordmann fir (Abies Nordmanniana) clonal seed orchards in Denmark

\begin{tabular}{|c|c|c|c|}
\hline & FP.251 & FP.272 & FP.259 \\
\hline Site & $\begin{array}{l}\text { Tuse } \\
\text { Næs }\end{array}$ & Skelhusmarken & $\begin{array}{l}\text { Silkeborg } \\
\text { Nordskov }\end{array}$ \\
\hline Latitude & $55^{\circ} 45^{\prime} \mathrm{N}$ & $56^{\circ} 46^{\prime} \mathrm{N}$ & $56^{\circ} 09^{\prime} \mathrm{N}$ \\
\hline Longitude & $11^{\circ} 42^{\prime} \mathrm{E}$ & $09^{\circ} 50^{\prime} \mathrm{E}$ & $09^{\circ} 34^{\prime} \mathrm{E}$ \\
\hline Material & Tversted & Tversted/F.20 & Tversted \\
\hline Established year & 2001 & 1997 & 1993 \\
\hline No. of trees evaluated & 1413 & 2033 & 1313 \\
\hline $\begin{array}{c}\text { No. of clones } \\
\text { evaluated }\end{array}$ & 62 & 65 & 68 \\
\hline Mean no. of ramets & 22 & 30 & 19 \\
\hline Min. no. of ramets & 13 & 3 & 12 \\
\hline Max. no. of ramets & 28 & 34 & 24 \\
\hline Area, ha & 3.5 & 9.7 & 3.2 \\
\hline
\end{tabular}

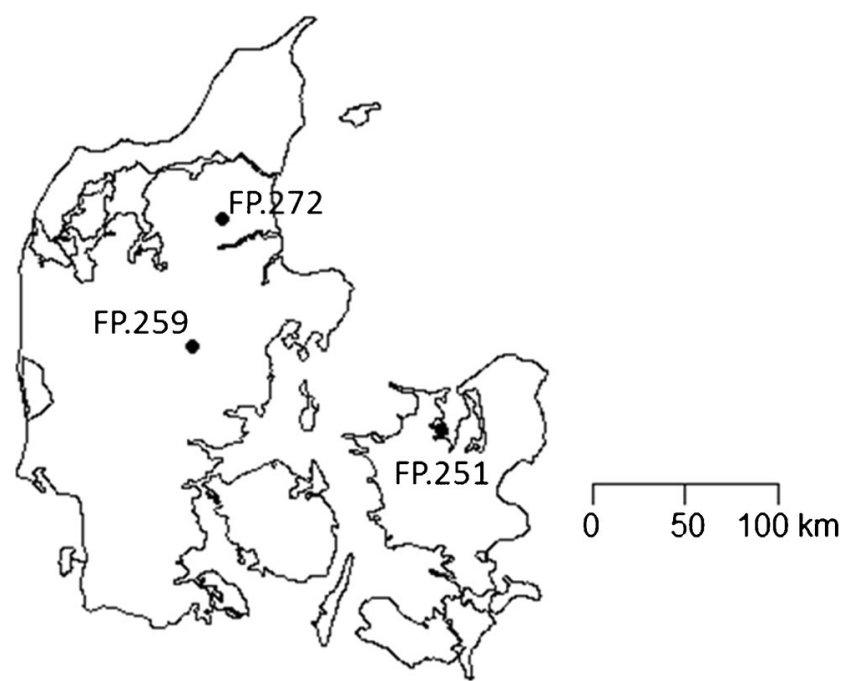

Fig. 1 Geographic location of the three evaluated Nordmann fir clonal seed orchards (CSOs) in Denmark

1992) in middle-aged second-generation stands that were offspring from F.20. Selection criteria included good health, crown shape, and dense branching. Among all three CSOs, 17 clones overlap, while 49, 18, and 21 clones overlap between FP.259 vs. FP.251, FP.272 vs. FP.251, and FP.272 vs. FP.259, respectively. Only FP.272 contains clones from both the Tversted and the F.20 gene pool-FP.251 and FP.259 only have Tversted material.

At each site, ramets of each clone were grafted in a nearly random pattern. Root stock was an open-pollinated commercial seed source. Row and column coordinates of each individual tree at the three sites were mapped on a regular grid. Subsequently, the program PPGBlock (Greg Dutkowski Personal Communication 2016) was used to create a complete rectangular grid of positions to enable a spatial analysis to be conducted in ASReml (Dutkowski et al. 2006).

Field evaluations in all CSOs were carried out in the winter of 2014. A scale from 0 to 10 , developed by Nielsen et al. (2017), was used to perform visual evaluation of each tree: score $=0$ : no sign of discolored shoots or dead branches; score $=1-3$ : a few damaged twigs, but the overall impression is still that of a rather healthy tree; score $=4-6$ : moderately damaged including single damaged branches to more pronounced damage, i.e., branches or part of the stem damaged, but still less than 50\%; score $=7-9$ : severely damaged including more than half of the tree damaged to large part of tree dead, dead or dying branches, but still a few living parts; and score = 10: dead tree, judged to be related to N. neomacrospora due to red fruiting bodies, heavy resin flow, etc.

Isolation of N. neomacrospora from trees in FP.251 and FP.259 was done after the field assessment. Both the white sporodochia of the anamorph stage and the red fruit bodies (perithecia) from the sexual stage of the fungus were recognized from trees that were cut down due to the canker symptoms in FP.251 and from living trees in FP.259 and FP.272. Identity was further confirmed based on the morphology of 
Fig. 2 Typical signs and symptoms of Neonectria neomacrospora infection on Nordmann fir. a Perithecia from the sexual stage of

$N$. neomacrospora on trees cut due to canker symptoms in FP.251. b Ascospores from the sexual stages of

N. neomacrospora. c

Macroconidia from the asexual stage of $N$. neomacrospora. (Photos: Jing $\mathrm{Xu}$ )
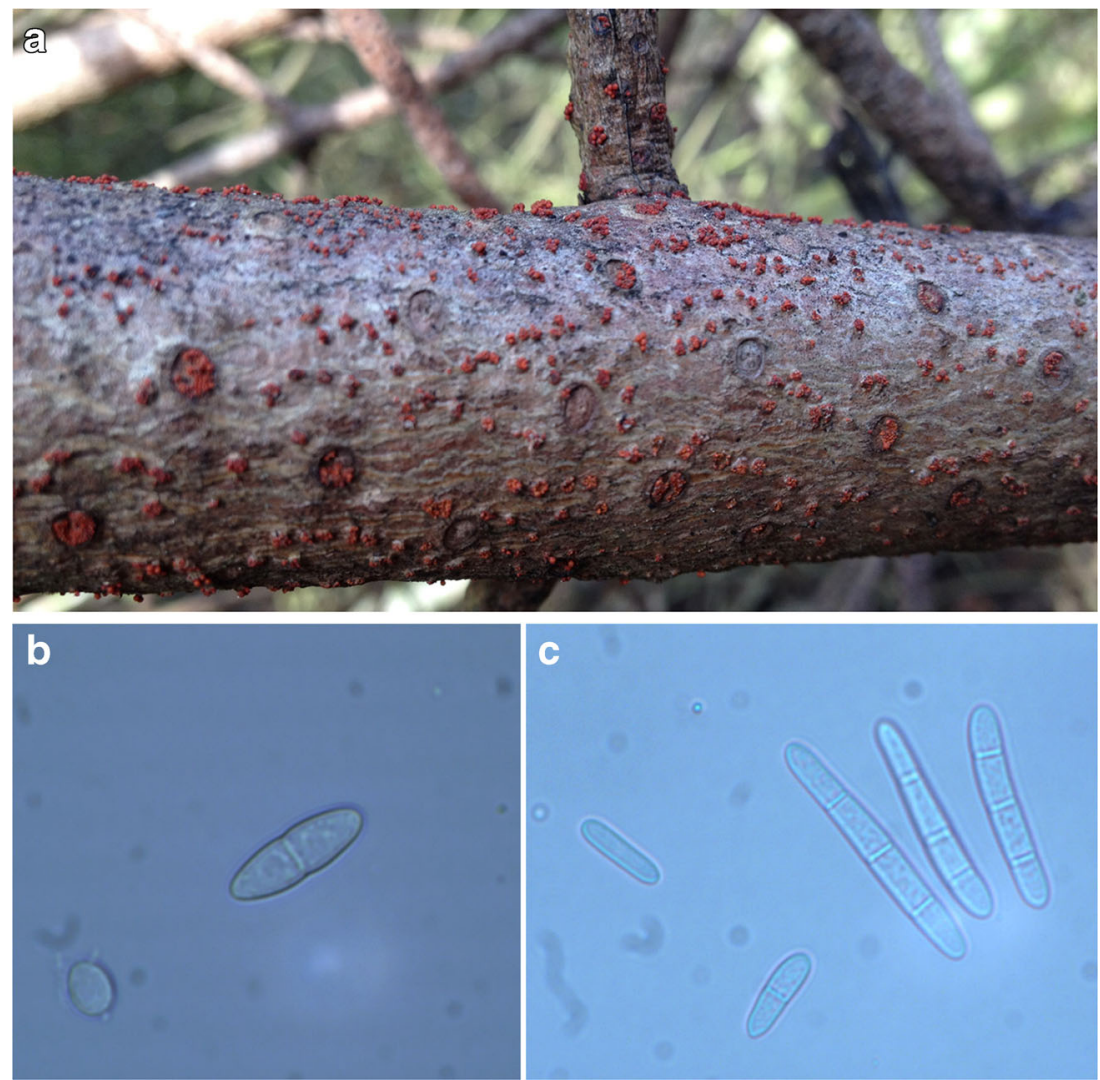

macroconidia and ascospores across three sites (Fig. 2). Mixes of macroconidia and ascospores collected from branches with the symptoms in FP.251 were used for an inoculation test of Nordmann fir, and the fungus was re-isolated from the inoculated shoots, thereby fulfilling Koch's postulates (Xu et al. in preparation).

\subsection{Statistical analysis}

\subsubsection{Single-site analyses}

In order to determine the most appropriate model for our data from each $\mathrm{CSO}$, the individual tree data regarding susceptibility to $N$. neomacrospora were first analyzed using a base model including several possible variables, where $N$. neomacrospora damage score acted as the response variable; fixed effects included the grand mean, edge row effect, and provenance effect; and random effects included clones. The random term was assumed to be a Gaussian random variable with an expectation of $\mathbf{0}$ and variance of $\mathbf{G}$ and $\mathbf{R}$. $\mathbf{R}$ is the variance-covariance matrix of residuals, and $\mathbf{G}$ is the variance-covariance matrix of the random effect.

The (co)variance components were estimated by REML (Patterson and Thompson 1971) using the average information REML algorithm (Gilmour et al. 1995) implemented in the ASReml-R 3.0 program (Butler et al. 2009). All the nonsignificant variance parameters were eliminated from the fitted models. Wald $F$ statistics was used to test the significance of fixed effects. The significance of the random effect was tested using a two-tailed likelihood ratio test (LRT) comparing the log-likelihood of the model with and without the random effect against the chi-square distribution with one degree of freedom. From this, a reduced base model with fixed effects of grand mean and edge row, as well as random effect of clone, was fitted for site FP.251, while for sites FP.259 and FP.272, reduced models with fixed effect of grand mean and random effect of clone were fitted.

Normal distribution of residuals in the base model was tested by a histogram of residuals in ASReml, and a plot of residuals against predicted values was used to check the assumption of homogeneity of residual variances. The visual inspection of residual plots did not reveal obvious deviation from normality and homogeneity.

After applying the reduced base model, a spatial analysis model was fitted at each site. Spatial analysis allows the $\boldsymbol{R}$ matrix to have alternative structures by partitioning the residuals $(\boldsymbol{e})$ into spatially correlated $(\boldsymbol{\xi})$ and independent $(\boldsymbol{\eta})$ residuals. The covariance structure used in this study assumed separable first-order autoregressive processes in rows and columns; the form of the $\boldsymbol{R}$ matrix is given by the following (Costa e Silva et al. 2001):

$R=\sigma_{\xi}^{2}\left[\operatorname{AR} 1\left(\rho_{\text {col }}\right) \otimes A R 1\left(\rho_{\text {row }}\right)\right]+\sigma_{\eta}^{2} I$ 
where $\sigma_{\xi}^{2}$ is the variance of spatially correlated residuals; AR1 $(\rho)$ are first-order autoregressive correlation matrices with autocorrelation parameters $\rho_{\text {col }}$ and $\rho_{\text {row }}$ for the columns and rows, respectively; $\otimes$ is the Kronecker product; $\sigma_{\eta}^{2}$ is the variance of the independent residuals; and $\boldsymbol{I}$ is an identity matrix.

At each site, the significance of the improvement achieved by using a spatial model was assessed using a LRT comparing the log-likelihood of the two models against the chi-square distribution with three degrees of freedom (Dutkowski et al. 2006).

Sample variograms were created in order to diagnose global and/or extraneous trends (Gilmour et al. 1997) after fitting the local trend in each CSO. The sample variogram is a plot of the semi-variances of differences of residuals between pairs of distances in the row/column directions. The nonstationary trend in the row/column direction in the variogram reflects the global trend.

\subsubsection{Combined clonal seed orchard analyses}

The expression of the same trait in different environments can be thought of as a different character (Falconer 1952), allowing for the study of genotype by environment $(\mathrm{G} \times \mathrm{E})$ interaction by estimating between-site genetic correlations. In our study, the extent of $\mathrm{G} \times \mathrm{E}$ interaction for the susceptibility to $N$. neomacrospora was evaluated using a multi-site spatial analysis model:

$\boldsymbol{y}=\boldsymbol{X} \boldsymbol{b}+\boldsymbol{Z} \boldsymbol{\mu}+\boldsymbol{\xi}+\boldsymbol{\eta}$

where $y$ is the combined vector of $N$. neomacrospora damage scores for three sites $\left(\boldsymbol{y}=\left(\boldsymbol{y}_{1}^{\mathbf{T}}, \boldsymbol{y}_{\mathbf{2}}^{\mathbf{T}}, \boldsymbol{y}_{3}^{\mathbf{T}}\right)^{\mathbf{T}}\right.$-where $\mathbf{T}$ is the transposition of a vector); $\boldsymbol{b}$ is the combined vector of fixed effects including the grand mean, site mean, and edge row effect at site FP.251 with its design matrix $\boldsymbol{X} ; \boldsymbol{\mu}$ is the combined vector of genotype effect within each site with design matrix $Z$; $\xi$ is the combined vector of spatially correlated residuals from each site; and $\boldsymbol{\eta}$ is the combined vector of independent residuals from each site.

In the multi-site analysis, we can have different genetic variances at each site. Therefore, a heterogeneous variance and correlation (CORGH) G structure was used to directly estimate the type- $\mathrm{B}$ genetic correlation $\left(r_{\mathrm{B}}\right)$ between sites:

CORGH G structure $=\left[\begin{array}{lll}\sigma_{c 1}^{2} & \rho_{12} & \rho_{13} \\ & \sigma_{c 2}^{2} & \rho_{23} \\ & & \sigma_{c 3}^{2}\end{array}\right]$

where $\rho_{\mathbf{1 2}}$ estimates $r_{\mathrm{B}}$ between sites FP.251 and FP.272, $\rho_{\mathbf{1 3}}$ estimates $\mathrm{r}_{\mathrm{B}}$ between sites FP.251 and FP.259, $\rho_{\mathbf{2 3}}$ estimates $r_{\mathrm{B}}$ between sites FP.272 and FP.259, and $\boldsymbol{\sigma}_{\boldsymbol{c} 1}^{2}$, $\sigma_{c 2}^{2}$, and $\sigma_{c 3}^{2}$ estimate the variance components for clones at each site.

\subsubsection{Genetic parameters}

Individual broad-sense heritability $\left(\boldsymbol{H}^{\mathbf{2}}\right)$ was estimated for each CSO as:

$\boldsymbol{H}^{2}=\frac{\sigma_{c}^{2}}{\sigma_{c}^{2}+\sigma_{\eta}^{2}}$

Standard errors were estimated using ASReml.

Best linear unbiased predictions (BLUPs) of genetic values of clones were obtained from the predicted values file of the spatial analysis at each site.

Data availability The data and the ASReml-R code are available from the data storage facility of the University of Copenhagen at the following addresses, respectively: http://www.erda.dk/public/archives/YXJjaGl2ZS0ySFVsdlA=/ published-archive.html and http://www.erda.dk/public/ archives/YXJjaGl2ZS1pWVEzMzE=/published-archive.html.

\section{Results}

\subsection{Infestation level}

The level of $N$. neomacrospora infestation was quite variable in the three studied CSOs. FP.259 was the most damaged site with only one healthy tree observed among 1313 evaluated trees (Fig. 3), and the best linear unbiased estimate (BLUE) for damage score was 3.85 (Table 2). FP.251 was the site with the least damage with $18.5 \%$ of healthy trees observed among 1413 evaluated trees (Fig. 3), and the BLUE for damage score was 1.86 (Table 2). Damage symptoms caused by $N$. neomacrospora were observed in all clones, but the damage extent (score) varied considerably among clones at each site. The breeding values of damage score ranged from -0.66 to 3.01 in FP.251, from 2.18 to 7.46 in FP.259, and from 0.54 to 5.99 in FP.272 (Table 2).

\subsection{Variance components and heritability}

The estimates of spatial model parameters from single-site analysis are presented in Table 2. The results showed a significant $(p<0.001)$ increase in log-likelihood by adding the spatially correlated residual term compared to the base model in all the analyses (data not shown), thereby justifying the spatial adjustment.

Variograms for the damage score of $N$. neomacrospora after fitting the spatial model are presented in Fig. 4. All three variograms indicate nonstationarity with a tendency for systematic changes in variance for both row and column (Gilmour et al. 1997), thereby revealing nonrandom spatial structures 
Fig. 3 Percentage of trees under each damage score level for Neonectria neomacrospora damage in the three clonal seed orchards in Denmark. Each bar represents the frequency of infected trees under each damage score at each site

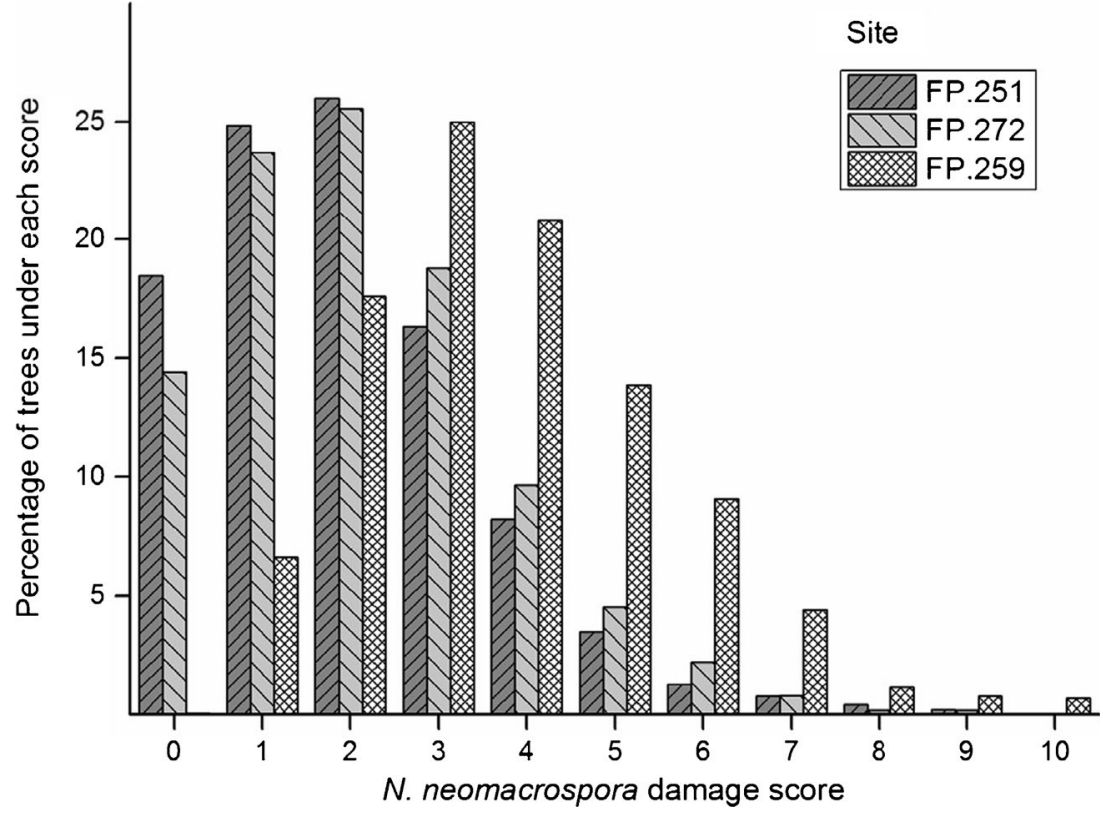

for $N$. neomacrospora damage in all three CSOs (Fig. 4). Put simply, these variograms show that damage scores for nearby trees were more similar than those for trees located far apart, reflecting spatial autocorrelation. Autocorrelation coefficients in column direction $\left(\rho_{\text {col }}\right)$ ranged from 0.85 to 0.95 , while autocorrelation coefficients in row direction $\left(\rho_{\text {row }}\right)$ ranged from 0.60 to 0.77 (Table 2). Clonal effect was significant $(p<0.001)$ for the spatial models at all sites. Estimates of $\boldsymbol{H}^{\mathbf{2}}$ for $N$. neomacrospora susceptibility after spatial adjustment were similar across the three sites, with values of 0.39 and 0.38 in FP.251 and FP.259, respectively, while the estimate for FP.272 was slightly higher at 0.47 .

Rank correlation between clonal BLUPs before and after spatial analysis was, on average, 0.99 within each site, which means that the two methods basically provide the same selections for further testing or deployment in new orchards.

\subsection{Genotype $\times$ environment variation}

All the CSOs were combined in a multi-site spatial analysis in order to estimate type-B genetic correlation for $N$. neomacrospora susceptibility. The average genetic correlation was 0.34 (Table 3 ) for $N$. neomacrospora damage score across sites, which represents significant $(p<0.001) \mathrm{G} \times \mathrm{E}$ interaction among all three CSOs. The low genetic correlations between FP.251 and both FP.259 (0.24) and FP.272 (0.29) (Table 3 ) indicate that there is little compliance between $N$. neomacrospora susceptibility at FP.251 and the other two sites with regard to ranking of clones. The relatively higher genetic correlation between FP.259 and FP.272 (0.49) (Table 3 ) reflects relatively higher correspondence for $N$. neomacrospora susceptibility between these two sites in ranking of clones.
Scatter plots of clonal breeding values at each site after fitting of the spatial analysis model for $N$. neomacrospora susceptibility were used to evaluate $\mathrm{G} \times \mathrm{E}$ interaction patterns (Fig. 5). It can be concluded from the plots that the statistically significant $\mathrm{G} \times \mathrm{E}$ interaction across the three sites is due both to scale effects and changes in clone performance across sites (Fig. 5).

\section{Discussion}

\subsection{Methodology}

The applied evaluation scale from 0 to 10 for the $N$. neomacrospora severity based on the damage symptoms has been used by both Nielsen et al. (2017) and Skulason et al.

Table 2 Variance parameters from the spatial models

\begin{tabular}{llll}
\hline \multirow{2}{*}{ Parameters } & Site & & \\
\cline { 2 - 4 } & FP.251 & FP.272 & FP.259 \\
\hline $\boldsymbol{\mu}$ & $1.86 \pm 0.24$ & $2.26 \pm 0.15$ & $3.85 \pm 0.19$ \\
$\boldsymbol{\sigma}_{\boldsymbol{c}}^{2}$ & $0.69 \pm 0.14^{*}$ & $1.04 \pm 0.19^{*}$ & $0.97 \pm 0.18^{*}$ \\
$\boldsymbol{\sigma}_{\boldsymbol{\eta}}^{\mathbf{2}}$ & $1.09 \pm 0.05^{*}$ & $1.19 \pm 0.04^{*}$ & $1.60 \pm 0.09^{*}$ \\
$\boldsymbol{\sigma}_{\xi}^{2}$ & $0.54 \pm 0.12$ & $0.29 \pm 0.05$ & $0.58 \pm 0.11$ \\
$\boldsymbol{\rho}_{\text {col }}$ & $0.95 \pm 0.01$ & $0.95 \pm 0.01$ & $0.85 \pm 0.04$ \\
$\boldsymbol{\rho}_{\text {row }}$ & $0.75 \pm 0.06$ & $0.60 \pm 0.09$ & $0.77 \pm 0.06$ \\
$\boldsymbol{H}^{\mathbf{2}}$ & $0.39 \pm 0.05$ & $0.47 \pm 0.05$ & $0.38 \pm 0.05$ \\
Breeding value range & {$[-0.66-3.01]$} & {$[0.54-5.99]$} & {$[2.18-7.46]$} \\
\hline
\end{tabular}

$\boldsymbol{\mu}$ best linear unbiased estimates (BLUEs), $\sigma_{c}^{2}$ clonal variance, $\sigma_{\eta}^{2}$ and $\sigma_{\xi}^{2}$ independent and correlated residual variances, $\rho_{\text {col }}$ and $\rho_{\text {row }}$ autocorrelation parameters for the columns and rows, $\boldsymbol{H}^{2}$ broad-sense heritability $* p$ value $<0.001$ 
Fig. 4 Variograms showing patterns of spatial variability for Neonectria neomacrospora damage in the three clonal seed orchards in Denmark. Row and col indicate distance lags in row and column direction at each site. The spatial trend is predicted for missing trees based on the correlation and values for neighbor trees

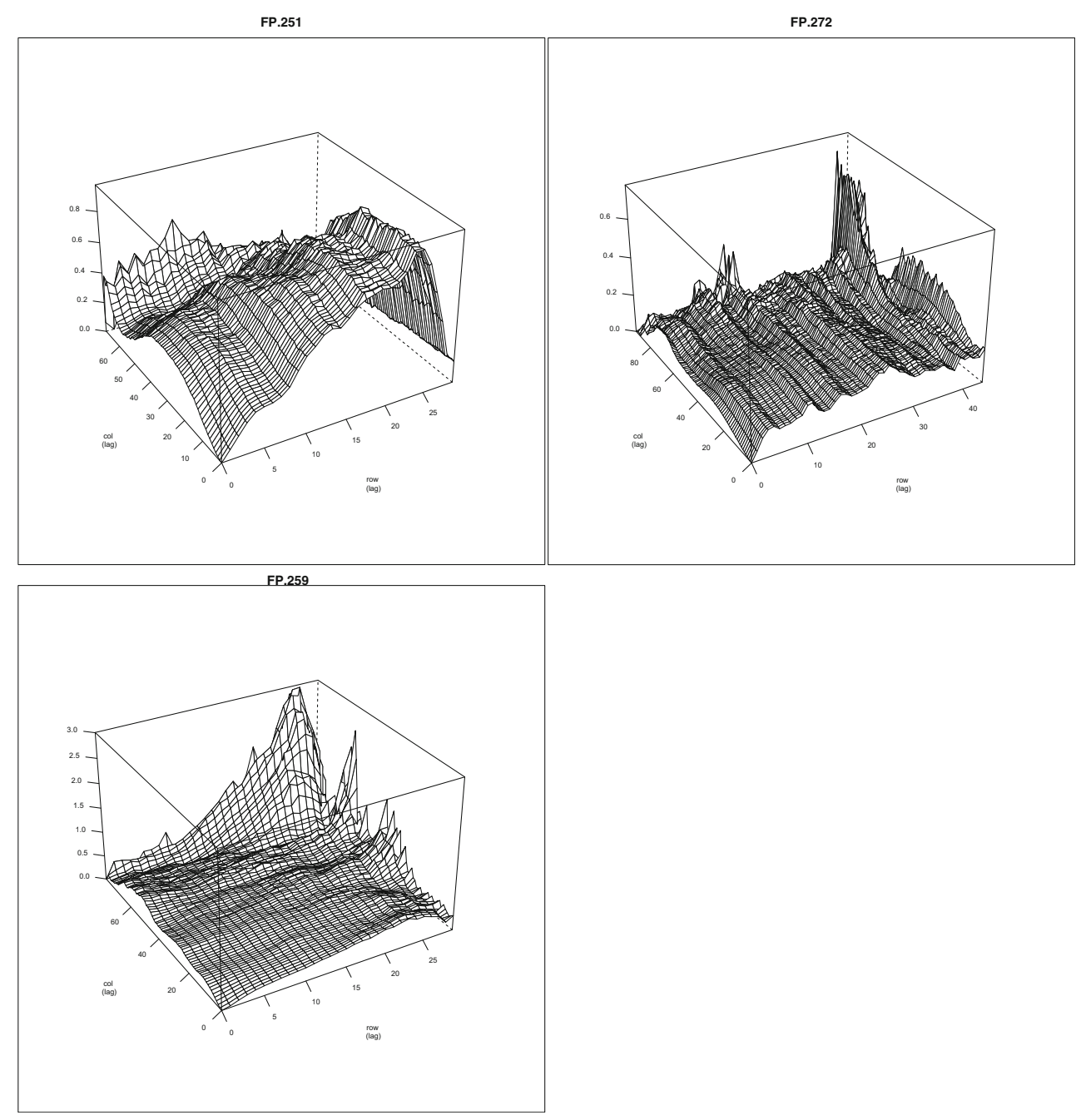

(2017), and in both studies, it correlated well with in vitro inoculation results. Therefore, we consider this damage evaluation scoring system to be a suitable measure of variation in the susceptibility of Nordmann fir to $N$. neomacrospora.

Compared to a commercial Christmas tree stand, the seed trees in a clonal seed orchard are established with larger spacing. However, at the stage where the disease scoring was made, the seed trees had reached a considerable size, and branches from neighboring trees were often touching each other. In that way, the infection conditions reflect the conditions in a Christmas tree stand close to the point of harvest. We

Table 3 Type-B genetic correlation between sites and associated standard errors

\begin{tabular}{llll}
\hline & FP.251 & FP.272 & FP.259 \\
\hline FP.251 & & & \\
FP.272 & $0.29 \pm 0.18$ & & \\
FP.259 & $0.24 \pm 0.14$ & $0.49 \pm 0.18$ & \\
\hline
\end{tabular}

have seen infection patterns in Christmas tree stands, but infected trees in those are normally removed quickly through sanitary cuttings, so it is difficult to draw a comparison.

Both the high autocorrelation between rows and columns and the inclined variograms reflect the patchy structure of the $N$. neomacrospora severity and incidence in all three CSOs, showing that the probability and extent of infection was not uniformly distributed within each site.

\subsection{Damage levels}

The abundance of healthy trees was very low in all three CSOs. Only $11 \%$ of the 4759 evaluated trees displayed no symptoms caused by $N$. neomacrospora in 2014 across the three CSOs. This suggests that the fungus is very aggressive in Nordmann fir. Talgø et al. (2013) pointed out that $N$. neomacrospora is a very aggressive pathogen to Abies species under both field conditions and in artificial inoculation tests. Nielsen et al. (2017) confirmed that 

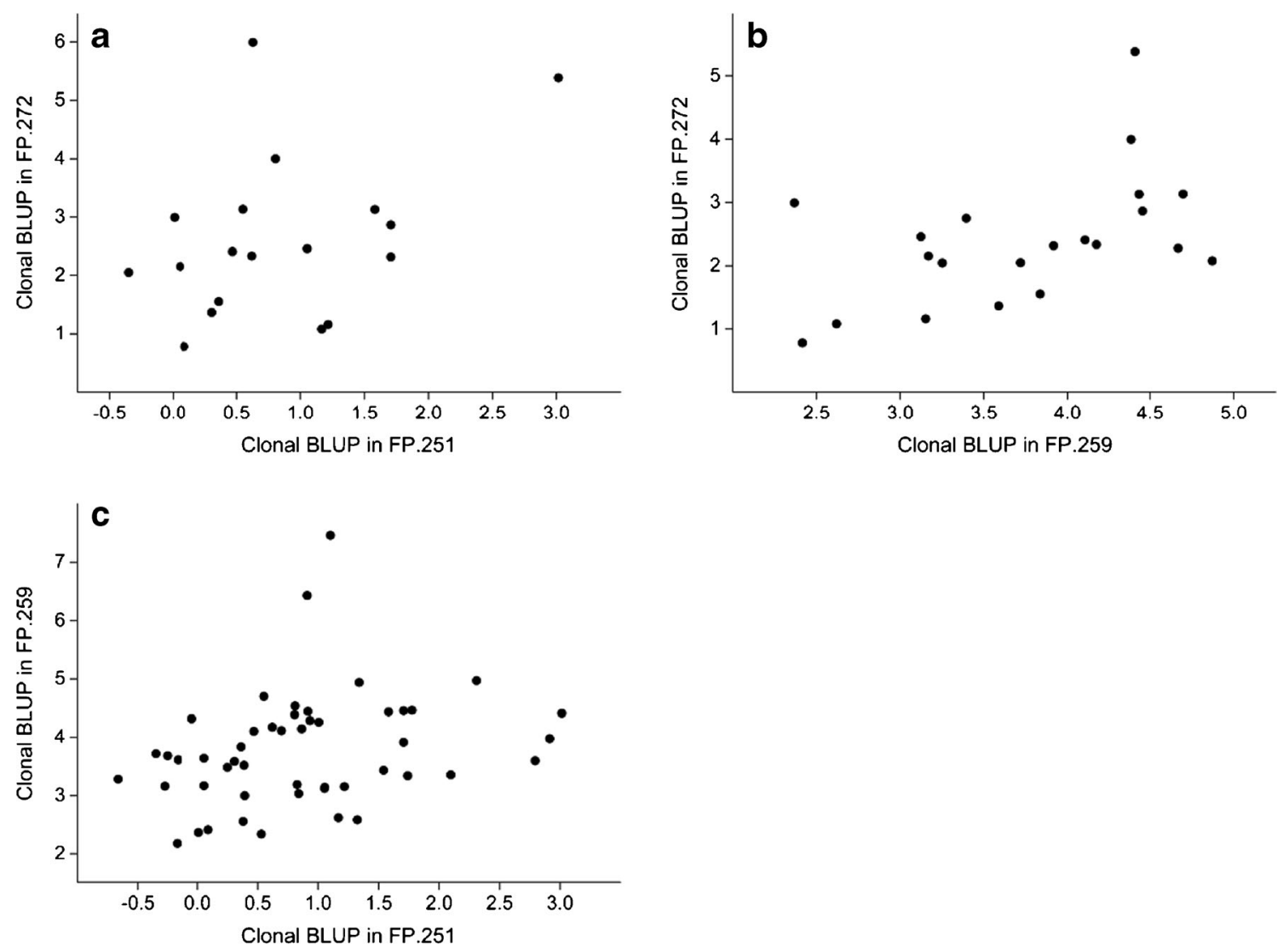

Fig. 5 Genotype by environment interaction for susceptibility to $N$. neomacrospora of Nordmann fir clones shared between sites. a Scatter plot of clonal values (BLUPs) of 18 clones shared between

FP.272 and FP.251. b Scatter plot of clonal values of 21 clones shared between FP.272 and FP.259. c Scatter plot of clonal values of 49 clones shared between FP.259 and FP.251

$N$. neomacrospora has a very broad range of hosts among Abies species, both under natural field infestation conditions and using in vitro inoculation tests. Skulason et al. (2017) also found that natural $N$. neomacrospora infections developed rapidly in three Danish provenance trials of A. lasiocarpa: The percentage of damaged trees increased from $40 \%$ in 2011 to $80 \%$ in 2014.

\subsection{Genetic variation in susceptibility}

In light of the above, the identification and deployment of Abies trees with natural genetic resistance to $N$. neomacrospora is very important, as the economic value of several Abies species used in Christmas tree industries around the world is substantial. Fortunately, variation in susceptibility was observed in the field and confirmed by in vitro inoculation among 39 Abies species (Nielsen et al. 2017) and 26 A. lasiocarpa provenances (Skulason et al. 2017). Our study detected a significant withinspecies variation in Nordmann fir. The 125 clones evaluated in the field responded very differently in terms of levels of symptoms following natural infections in each CSO. Although no clone was totally free of damage symptoms, there were clones with an average damage score close to 0 , as observed, for

example, in clones 80 (mean score 0.3 ) and 70 (mean score 0.5 ) in FP.251 and clones 9021 (mean score 0.3) and 9045 (mean score 0.5) in FP.272. The clonal variance component accounted for between 38 and $47 \%$ of the total phenotypic variation in the CSOs.

Worldwide, $60 \%$ of research activities involving breeding for insect and disease resistance in forest trees have shown genetic variation in resistance in seedling or clonal screens (FAO 2008). Clones tolerant to Dutch elm disease caused by Ophiostoma ulmi and Ophiostoma novo-ulmi in Ulmus have been observed across North America and Europe (Martín et al. 2015; Pinon et al. 2005; Solla et al. 2005; Townsend et al. 2005). Also, genetic variation in resistance to ash dieback caused by Hymenoscyphus fraxineus in Fraxinus excelsior has been reported from several countries in Europe (Kirisits and Freinschlag 2012; Lobo et al. 2015; McKinney et al. 2011; Pliūra and Baliuckas 2007; Pliūra et al. 2016; Muñoz et al. 2016; Stener 2013). In displays and tests of apple cultivars, a continuous variation has also been seen for partial resistance to canker disease caused by the fungus Neonectria ditissima in Europe (Borecki and Czynczyk 1985; Garkava-Gustavsson et al. 2013; Ghasemkhani et al. 2015; Sasnauskas et al. 2006; Vandeweg 1989). The presence of natural genetic variation in 
susceptibility to $N$. neomacrospora opens up prospects for adapting Nordmann fir to this canker disease through the selection of less susceptible trees. Further analysis of progeny tests may provide additional insight into the genetic inheritance of resistance to $N$. neomacrospora.

\subsection{Genotype by environment interaction}

$\mathrm{G} \times \mathrm{E}$ interaction was found to be highly significant $(p<0.001)$ for susceptibility of Nordmann fir to $N$. neomacrospora, indicating that clonal resistance to $N$. neomacrospora was unstable across the three environments. The largest $\mathrm{G} \times \mathrm{E}$ interaction was between FP.251 and the other two sites, due to the low genetic correlations between FP.251 and sites FP.259 (0.24) and FP.272 (0.29). This indicates that there was hardly any relationship between FP.251 and the other two sites in the relative ranking of clonal susceptibility to $N$. neomacrospora. As mentioned above, clones 70 and 80 were almost without damage symptoms in FP.251, while these two clones had an average damage score of respectively 3.2 and 3.8 in FP.259, and clone 70 had an average damage score of 2.0 in FP.272, emphasizing the instability of clonal performance of $N$. neomacrospora susceptibility across sites.

The significant $G \times E$ interaction found in our study may have at least three explanations. First of all, the environmental heterogeneity among CSOs resulting from biotic (e.g., pathogens, insects, and weeds) or abiotic (e.g., temperature, rainfall, and soil quality) factors may, to some extent, modulate the clonal performance in relation to $N$. neomacrospora. The difference in average damage score among the three CSOs may, for example, be due to different pathogen pressure among these sites, meaning that the number of effective pathogen propagules was different among sites (Ennos 2015). McCracken et al. (2003) stated that surrounding infected orchards were the major source of inoculum of $N$. ditissima (syn. Neonectria galligena), which cause European canker and fruit rot in apples. We also believe that this is a potential reason for the infection severity at our three sites. Sites FP.259 and FP.272 are located in forest areas with a high density of forest trees including Abies trees, and the chance of more $N$. neomacrospora-infected trees in the surroundings is therefore also higher than for FP.251, which is located in an open farmland area. Compared with FP.259, FP.272 is more open, with only two sides being connected or close to forest areas and the other two sides being connected to open farm land, so in this case, the inoculum pressure is potentially lower in FP.272 than in FP.259. It has been documented that temperature and moisture duration are important determinants of the risk of infection by $N$. galligena in apples (Latorre et al. 2002; Xu et al. 1998), and rainfall is a major factor in the geographic distribution of this disease (Latorre et al. 2002; Xu et al.
1998) since rain is an important vector for spore production, spread, germination, and infection (McCracken et al. 2003). Thus, different amounts or frequencies of rainfall could also cause different extents of infection by $N$. neomacrospora. Additionally, a substantial amount of damage caused by the silver fir wooly adelgid (Dreyfusia nordmanniana) was observed (data not shown) in FP.251, while only a few trees were observed with adelgid damage at the other two sites. Many studies have shown that insects possibly enhance fungal infection in host plants by suppressing critical defenses (Agrios 1980; De Zutter et al. 2017; Drakulic et al. 2015; Halik and Bergdahl 2002). Therefore, Nordmann fir susceptibility to $N$. neomacrospora may be affected by an attack of $D$. nordmanniana, so if there are clonal differences in susceptibility to D. Nordmanniana as well, this may cause the difference in ranking between FP.251 and the other two sites with regard to $N$. neomacrospora susceptibility. Skulason et al. (2017) found that damage caused by a closely related adelgid, Adelges piceae, increased the risk of infection on A. lasiocarpa by $N$. neomacrospora at an early stage of the disease outbreak. In our study, FP.251 showed more damage caused by $D$. nordmanniana than the other two sites, but the $N$. neomacrospora damage was lower, which again suggests that the extent of $N$. neomacrospora infection is not only affected by one factor, but is the result of several potential factors.

A second potential cause of the different ranking of host genotypes for resistance at different sites is possible variation in pathogen virulence and different frequencies of virulence genes in pathogen populations at different sites (Carson and Carson 1989). Scheper et al. (2015) found that there are significant differences in pathogenicity among three different strains of $N$. ditissima. McKeand et al. (1999) hypothesized that some Loblolly pine families' unstable performance across sites may be due to the interaction between their susceptibility and specific pathogen virulence among sites. Therefore, understanding both the genetics of virulence and variability in virulence of $N$. neomacrospora can assist in exploring the underlying reasons for variation in disease expression across environments (Carson and Carson 1989). Lastly, unknown factors may have affected disease expression. Xu et al. (1998) reported that several factors affect the artificial infection of apples by $N$. ditissima, such as inoculum dose, duration of wet period, temperature, and wound age. Since $N$. ditissima is closely related to $N$. neomacrospora (Talgø et al. 2012), we think that similar factors may relate to the variation of clonal susceptibility across sites and among individual trees.

In summary, the variation of clonal susceptibility to $N$. neomacrospora across sites may be attributed to biotic factors such as different pathogen pressure and different numbers of adelgids at those sites, to the variation of pathogen virulence and different frequencies of virulence genes in 
pathogen populations across sites, to local or seasonal differences in precipitation and temperature, and to other unknown factors. Selection for resistance to $N$. neomacrospora among Nordmann firs should therefore consider the genotype stability across sites. Attention also needs to be paid to the genetics of virulence and variability in virulence of $N$. neomacrospora.

\section{Conclusions}

Neonectria neomacrospora damage was serious in all three CSOs, and none of the Nordmann fir clones were completely resistant to $N$. neomacrospora. Substantial and significant clonal variation and moderate to high broad-sense heritability estimates in damage scores at each site suggest a substantial quantitative resistance to the disease, but further investigations of narrow-sense heritability and expression of the trait in younger material are desirable. The presence of significant genotype by environment interactions and substantial ranking changes in clonal performance between sites shows that the susceptibility of Nordmann fir to $N$. neomacrospora is unequal across different environments, which may be due to different pressures caused by either $N$. neomacrospora or adelgids, or both, or due to the variation in pathogen virulence or climatic factors at different sites. Further studies on the variation of $N$. neomacrospora virulence also need to be considered.

Acknowledgements We give thanks to Timothy Robert Dowse and Lars Nørgaard Hansen who carried out the field evaluations and to Knud Nor Nielsen for helping with data transformation in R. We are grateful to the anonymous reviewer and the associate editors Cécile Robin and Erwin Dreyer for their critical reviews and suggestions.

Funding information The GB Hartmann family foundation grant no. 11, 2014-2015, part 3, Danish Nature Agency and Vemmetofte Kloster, which we gratefully acknowledge for supporting this study. We also thank the Chinese Scholarship Council (CSC) for providing the Ph.D. scholarship to Jing Xu.

\section{References}

Agrios GN (1980) Insect involvement in the transmission of fungal pathogens. In: Harris FK, Maramorosch K (eds) Vectors of plant pathogens. Academic Press, New York, pp 293-324. https://doi.org/10. 1016/B978-0-12-326450-3.50017-6

Borecki Z, Czynczyk A (1985) Susceptibility of apple cultivars to bark canker diseases. Acta Agrobot 38:49-59

Burdon RD (1977) Genetic correlation as a concept for studying genotype-environment interaction in forest tree breeding. Silvae Genet 26:5-6

Butler DG, Cullis BR, Gilmour AR, Gogel BJ (2009) ASReml-R reference manual. The State of Queensland, Department of Primary Industries and Fisheries, Brisbane
Carson SD, Carson MJ (1989) Breeding for resistance in forest trees-a quantitative genetic approach. Annu Rev Phytopathol 27(1):373395. https://doi.org/10.1146/annurev.py.27.090189.002105

Codesido V, Fernández-López J (2009) Implication of genotype $\times$ site interaction on Pinus radiata breeding in Galicia. New For 37(1): 17 34. https://doi.org/10.1007/s11056-008-9105-8

Costa e Silva J, Dutkowski GW, Gilmour AR (2001) Analysis of early tree height in forest genetic trials is enhanced by including a spatially correlated residual. Can J For Res 31(11):1887-1893. https://doi. org/10.1139/x01-123

Cullis BR, Gleeson AC (1991) Spatial analysis of field experiments-an extension to two dimensions. Biometrics 47(4):1449-1460. https:// doi.org/10.2307/2532398

Danish Agrifish Agency (2016) Kårede frøavlsbevoksninger i Danmarks skove. Ministry of Food and Environment. http://naturerhverv.dk/ fileadmin/user_upload/NaturErhverv/Filer/Landbrug/Skovbrug/ Kaaring/3153KAAR_Liste_over_dansk_grundmateriale.pdf Accessed, December 2016

De Zutter N, Audenaert K, Ameye M, De Boevre M, De Saeger S, Haesaert G, Smagghe G (2017) The plant response induced in wheat ears by a combined attack of Sitobion avenae aphids and Fusarium graminearum boosts fungal infection and deoxynivalenol production. Mol Plant Pathol 18(1):98-109. https://doi.org/10.1111/mpp. 12386

Drakulic J, Caulfield J, Woodcock C, Jones SPT, Linforth R, Bruce TJA, Ray RV (2015) Sharing a host plant (wheat [Triticum aestivum]) increases the fitness of Fusarium graminearum and the severity of Fusarium head blight but reduces the fitness of grain Aphids (Sitobion avenae). Appl Environ Microbiol 81(10):3492-3501. https://doi.org/10.1128/aem.00226-15

Dutkowski GW, Costa e Silva J, Gilmour AR, Lopez GA (2002) Spatial analysis methods for forest genetic trials. Can J For Res 32(12): 2201-2214. https://doi.org/10.1139/x02-111

Dutkowski GW, Costa e Silva J, Gilmour AR, Wellendorf H, Aguiar A (2006) Spatial analysis enhances modelling of a wide variety of traits in forest genetic trials. Can J For Res 36(7):1851-1870. https://doi.org/10.1139/x06-059

Ennos RA (2015) Resilience of forests to pathogens: an evolutionary ecology perspective. Forestry 88(1):41-52. https://doi.org/10.1093/ forestry/cpu048

Falconer DS (1952) The problem of environment and selection. Am Nat 86(830):293-298. https://doi.org/10.1086/281736

FAO (2008) Selection and breeding for insect and disease resistance. Food and Agricultural Organization of the United Nations. http:// www.fao.org/forestry/26445/en/ Accessed, December 2016

Fu YB, Yanchuk AD, Namkoong G (1999) Spatial patterns of tree height variations in a series of Douglas-fir progeny trials: implications for genetic testing. Can J For Res 29(6):714-723. https://doi.org/10. 1139/x99-046

Garkava-Gustavsson L, Zborowska A, Sehic J, Rur M, Nybom H, Englund JE, Lateur M, Van de Weg E, Holefors A. (2013) Screening of apple cultivars for resistance to European canker, Neonectria ditissima. In: Proceeding of the 13th Eucarpia Symposium on Fruit Breeding and Genetics, Leuven, Belgium. Acta Hort 976:529-536. doi: https://doi.org/10.17660/ActaHortic. 2013.976.75

Ghasemkhani M, Liljeroth E, Sehic J, Zborowska A, Nybom H (2015) Cut-off shoots method for estimation of partial resistance in apple cultivars to fruit tree canker caused by Neonectria ditissima. Acta Agric Scand Sect B Soil Plant Sci 65(5):412-421. https://doi.org/10. 1080/09064710.2015.1016101

Gilmour AR, Thompson R, Cullis BR (1995) Average information REML: an efficient algorithm for variance parameter estimation in linear mixed models. Biometrics 51(4):1440-1450. https://doi.org/ $10.2307 / 2533274$ 
Gilmour A, Cullis B, Verbyla A (1997) Accounting for natural and extraneous variation in the analysis of field experiments. J Agric Biol Environ Stat 2(3):269-293. https://doi.org/10.2307/1400446

Gómez-Cortecero A, Saville RJ, Scheper RWA, Bowen JK, De Medeiros $\mathrm{H}$, Kingsnorth J, Xu X, Harrison RJ (2016) Variation in host and pathogen in the Neonectria/Malus interaction; toward an understanding of the genetic basis of resistance to European canker. Front Plant Sci 7:1365. https://doi.org/10.3389/fpls.2016.01365

Halik S, Bergdahl DR (2002) Potential beetle vectors of Sirococcus clavigignenti-juglandacearum on butternut. Plant Dis 86(5):521527. https://doi.org/10.1094/PDIS.2002.86.5.521

John R (2011) Tannen-Rindennekrose in Baumhölzern. AFZ - Der Wald 66:30-33

Joshi AK, Kumari M, Singh VP, Reddy CM, Kumar S, Rane J, Chand R (2007) Stay green trait: variation, inheritance and its association with spot blotch resistance in spring wheat (Triticum aestivum L.) Euphytica 153(1-2):59-71. https://doi.org/10.1007/s10681-0069235-z

Kirisits T, Freinschlag C (2012) Ash dieback caused by Hymenoscyphus pseudoalbidus in a seed plantation of Fraxinus excelsior in Austria. East Afr J Rural Dev 4(9):184-191. https://doi.org/10.5897/jaerd12. 046

Lang KJ (1981) Cylindrocarpon cylindroides var. tenue als pathogen an Abies concolor und einigen Tannenbastarden. Eur J Forest Pathol 11(3):191-192. https://doi.org/10.1111/j.1439-0329.1981.tb00086. $\mathrm{x}$

Latorre BA, Rioja ME, Lillo C, Munoz M (2002) The effect of temperature and wetness duration on infection and a warning system for European canker (Nectria galligena) of apple in Chile. Crop Prot 21(4):285-229. https://doi.org/10.1016/S0261-2194(01)00099-0

Liu T (1971) A Monograph of the Genus Abies. Dissertation, Department of Forestry, College of Agriculture, National Taiwan University

Lobo A, Hansen JK, McKinney LV, Nielsen LR, Kjær ED (2014) Genetic variation in dieback resistance: growth and survival of Fraxinus excelsior under the influence of Hymenoscyphus pseudoalbidus. Scand J For Res 29(6):519-526. https://doi.org/10.1080/ 02827581.2014 .950603

Lobo A, McKinney LV, Hansen JK, Kjær ED, Nielsen LR (2015) Genetic variation in dieback resistance in Fraxinus excelsior confirmed by progeny inoculation assay. Forest Pathol 45(5):379-387. https://doi. org/10.1111/efp.12179

Løfting ECL (1973) Statusopgørelse for nordmannsgran. Det forstlige Forsøgsvæsen i Danmark 33:305-326

Mantiri FR, Samuels GJ, Rahe JE, Honda BM (2001) Phylogenetic relationships in Neonectria species having Cylindrocarpon anamorphs inferred from mitochondrial ribosomal DNA sequences. Can J Bot 79:334-340

Martín J, Solla A, Venturas M, Collada C, Domínguez J, Miranda E, Fuentes P, Burón M, Iglesias S, Gil L (2015) Seven Ulmus minor clones tolerant to Ophiostoma novo-ulmi registered as forest reproductive material in Spain. iForest 8(2):172-180. https://doi.org/10. 3832/ifor1224-008

McCracken AR, Berrie A, Barbara DJ, Locke T, Cooke LR, Phelps K, Swinburne TR, Brown AE, Ellerker B, Langrell SRH (2003) Relative significance of nursery infections and orchard inoculum in the development and spread of apple canker (Nectria galligena)in young orchards. Plant Pathol 52(5):553-566. https://doi.org/10. 1046/j.1365-3059.2003.00924.x

McKeand S, Li B, Amerson H (1999) Genetic variation in fusiform rust resistance in loblolly pine across a wide geographic range. Silvae Genet 48:255-259

McKinney LV, Nielsen LR, Hansen JK, Kjær ED (2011) Presence of natural genetic resistance in Fraxinus excelsior (Oleracea) to Chalara fraxinea (Ascomycota): an emerging infectious disease. Heredity 106(5):788-797. https://doi.org/10.1038/hdy.2010.119
Muñoz F, Marçais B, Dufour J, Dowkiw A (2016) Rising out of the ashes: additive genetic variation for crown and collar resistance to Hymenoscyphus fraxineus in Fraxinus excelsior. Phytopathology 106(12):1535-1543. https://doi.org/10.1094/PHYTO-11-15-0284-R

Nielsen UB (1994) Breeding noble fir (Abies procera Rehder) and Nordmann fir (Abies nordmanniana (Stev.) Spach) for Christmas trees and greenery in Denmark. Lee SJ (ed) In: Proceedings of the Nordic Group for Tree Breeding, Forestry Commission, Edinburgh, Scotland, 1993. 118-127

Nielsen UB, Chastagner GA (2005) Genetic variation in postharvest needle retention among Nordmann fir families and grafted clones. Scand J For Res 20(4):304-312. https://doi.org/10.1080/ 02827580510008365

Nielsen UB, Xu J, Nielsen KN, Talgø V, Hansen OK, Thomsen IM (2017) Species variation in susceptibility to the fungus Neonectria neomacrospora in the genus Abies. Scan J For Res 32(5):421-431. https://doi.org/10.1080/02827581.2017.1287300

Ogut F, Maltecca C, Whetten R, McKeand S, Isik F (2014) Genetic analysis of diallel progeny test data using factor analytic linear mixed models. For Sci 60(1):119-127. https://doi.org/10.5849/ forsci.12-108

Patterson HD, Thompson R (1971) Recovery of inter-block information when block sizes are unequal. Biometrika 58(3):545-554. https:// doi.org/10.1093/biomet/58.3.545

Pinon J, Husson C, Collin E (2005) Susceptibility of native French elm clones to Ophiostoma novo-ulmi. Ann For Sci 62(7):689-696. https://doi.org/10.1051/forest:2005066

Pliūra A, Baliuckas V (2007) Genetic variation in adaptive traits of progenies of Lithuanian and western European populations of Fraxinus excelsior L. Balt For 13:28-38

Pliūra A, Lygis V, Marciulyniene D, Suchockas V, Bakys R (2016) Genetic variation of Fraxinus excelsior half-sib families in response to ash dieback disease following simulated spring frost and summer drought treatments. iForest 9(1):12-22. https://doi.org/10.3832/ ifor1514-008

Proschowsky GF (2014) Naturstyrelsen Nordsjælland-Brancheindsats mod Neonectria. Skovplanteringens årsmøde, 14. januar 2014. http://www.danskeplanteskoler.dk/Skovplanteringen/pics/6.pdf

Resende MDV, Thompson R, Welham SJ (2006) Multivariate spatial statistical analysis of longitudinal data in perennial crops. Rev Mat Estatíst 24:147-169

Rietman LM (2004) Assessment of Neonectria neomacrospora as a potential biological control agent for hemlock dwarf mistletoe. Dissertation, The University of British Columbia

Rietman LM, Shamoun SF, Kamp BJVD (2005) Assessment of Neonectria neomacrospora (anamorph Cylindrocarpon cylindroides) as an inundative biocontrol agent against hemlock dwarf mistletoe. Can J Plant Pathol 27(4):603-609. https://doi.org/ $10.1080 / 07060660509507261$

Robak H (1951) Observations on the relationship between climatic damages and fungi damage on conifers [Noen iagttagelser til belysning av forholdet mellom klimatiske skader og soppangrep på nåletrær]. Meddr Vestland forstl ForsStn. 8:1-43(in Norwegian)

Sasnauskas A, Gelvonauskiene D, Gelvonauskis B, Bendokas V, Baniulis D (2006) Resistance to fungal diseases of apple cultivars and hybrids in Lithuania. Agron Res 4:349-352

Scheper RWA, Frijters L, Fisher BM, Hedderley DI (2015) Effect of freezing of Neonectria ditissima inoculum on its pathogenicity. $\mathrm{N}$ Z Plant Prot 68:257-263

Skulason B, Hansen OK, Thomsen IM, Talgø V, Nielsen UB (2017) Damage by Neonectria neomacrospora and Adelges piceae in provenance trials of subalpine fir (Abies lasiocarpa) in Denmark. For Pathol 47(3). https://doi.org/10.1111/efp.12326

Solla A, Bohnens J, Collin E, Diamandis S, Franke A, Gil L, Buron M, Santini A, Mittempergher L, Pinon J, Broeck AV (2005) Screening 
European elms for resistance to Ophiostoma novo-ulmi. For Sci 51: 134-141

Stener LG (2013) Clonal differences in susceptibility to the dieback of Fraxinus excelsior in southern Sweden. Scand J For Res 28(3):205216. https://doi.org/10.1080/02827581.2012.735699

Talgø V, Thomsen IM, Nielsen UB, Brurberg MB, Stensvand A (2012) Neonectria canker on subalpine fir (Abies lasiocarpa) in Denmark. In: Proceedings of the $10^{\text {th }}$ International Christmas Tree Research \& Extension Conference, Eichgraben, pp 92-96

Talgø V, Brurberg MB, Stensvand A, Thomsen IM (2013) Neonectria neomacrospora is threatening the true fir production in Scandinavia. In: Proceeding of The $11^{\text {th }}$ International Christmas Tree Research and Extension Conference, Faculty of Agriculture, , Nova Scotia, Canada, p 28
Townsend AM, Bentz SE, Douglass LW (2005) Evaluation of 19 American elm clones for tolerance to Dutch elm disease. J Environ Hortic 23:21-24

Vandeweg WE (1989) Screening for resistance to Nectria galligena Bres. in cut shoots of apple. Euphytica 42(3):233-240. https://doi.org/10. 1007/BF00034459

Wollenweber HW (1913) Ramularia, mycosphaerella, nectria, calorectria. Phytopathology 3(4):198-243

Xu XM, Butt DJ, Ridout MS (1998) The effects of inoculum dose, duration of wet period, temperature and wound age on infection by Nectria galligena of pruning wounds on apple. Eur J Plant Pathol 104(5):511-519. https://doi.org/10.1023/a:1008689406350

Ye TZ, Jayawickrama KJS (2008) Efficiency of using spatial analysis in first-generation coastal Douglas-fir progeny tests in the US Pacific Northwest. Tree Genet Genomes 4(4):677-692. https://doi.org/10. 1007/s11295-008-0142-4 